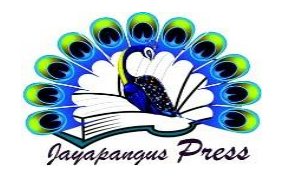

\title{
Analisis Faktor Penyebab dan Dampak Kualitas Belajar Mahasiswa Berbasis Daring di Masa Pandemi Covid-19
}

\author{
Wayan Supada ${ }^{1}$, Gusti Ayu Putu Diah Permata Sari², I Gede Teguh Heriawan², \\ I Gede Titah Pratyaksa ${ }^{4}$ \\ Sekolah Tinggi Agama Hindu Negeri Mpu Kuturan Singaraja \\ ${ }^{1}$ wsupada@gmail.com, ${ }^{2}$ diahpermatasari.ar@gmail.com, \\ 33edeteguh@stahnmpukuturan.ac.id, ${ }^{4}$ titahpratyaksa@gmail.com
}

\begin{tabular}{l}
\hline Keywords: \\
\hline E-Learning; \\
Lecturer \\
Competence; \\
Motivation; \\
Learning \\
Quality; \\
Learning \\
Effectiveness \\
\hline
\end{tabular}

\begin{abstract}
The e-learning system can create individuation, enrichment, acceleration, expansion, productivity and effectiveness in learning so that the quality of education can increase during the Covid-19 pandemic. This research was conducted to find the right formulation of the online lecture system in the future. In this study, the research population was all students of the communication science study program, totaling 259 people. For the needs of analysis and hypothesis testing, the entire population is used as the research sample. So the research is included in population research. The analytical technique used in this study uses a structural equation model (SEM) with the AMOS 21.0 program which consists of several stages. The results showed that of the nine paths and hypotheses built, seven hypotheses had a positive and significant effect, while two hypotheses had an insignificant effect.
\end{abstract}

Kata Kunci:

E-Learning;

Kompetensi

Dosen; Motivasi;

Kualitas Belajar;

Efektivitas

Belajar

\begin{abstract}
Abstrak
Sistem e-learning dapat menciptakan individuasi, pengayaan, akselerasi, perluasaan, produktivitas dan efektifitas dalam pembelajaran sehinggga kualitas pendidikan dapat meningkat selama masa Pandemi Covid-19. Penelitian ini dilakukan untuk menemukan formulasi yang tepat tentang sisitem perkuliahan online ke depan. Dalam penelitian ini, yang menjadi populasi penelitian adalah seluruh mahasiswa prodi ilmu komunikasi yang berjumlah sebanyak 259 orang. Untuk kebutuhan analisis dan pengujian hipotesis, seluruh populasi dijadikan sebagai sampel penelitian. Sehingga penelitian termasuk dalam penelitian populasi. Teknik analisis yang digunakan dalam penelitian ini menggunakan structural equation model (SEM) dengan program AMOS 21.0 yang terdiri dari beberapa tahapan. Hasil penelitian menunjukkan bahwa dari sembilan jalur dan hipotesis yang dibangun, tujuh hipotesis memiliki pengaruh yang positif dan signifikan sedangkan dua hipotesis memiliki pengaruh yang tidak signifikan.
\end{abstract}




\section{Pendahuluan}

Dalam proses implementasinya, beberapa fenomena positif dan negatif ditemukan terhadap pelaksanaan sistem perkuliahan daring atau online yang dilakukan oleh perguruan tinggi. Hasil penelitian Kusnayat, dkk (2020) menemukan bahwa penelitian di kampus Telkom University dan UIN SGD Bandung menunjukkan sekitar 60,5\% mahasiswa siap beradaptasi dengan penggunaan teknologi pembelajaran perkuliahan online tetapi sekitar 59,5\% keberatan atas tugas yang diberikan dosen yang berakibat tingkat stress mahasiswa sekitar $60 \%$. Kalau hal ini dibiarkan terus akan berakibat fatal dalam perkembangan kejiwaan mahasiswa, dan sebanyak $92 \%$ mahasiswa memilih dan lebih suka perkuliahan tatap muka di kelas di banding perkuliahan online. Sehingga penelitian ini ada hubungan yang erat antara perkuliahan online dengan sikap mental mahasiswa. Perubahan pembelajaran tatap muka menjadi pembelajaran online yang dilaksanakan secara mendadak membuat pembelajaran tidak dapat berjalan dengan maksimal (Irawati \& Jonatan, 2020). Seiring berjalannya waktu pembelajaran jarak jauh menjadi berdampak pada psikologis mahasiswa (Kartika, 2020). Sejalan dengan penelitian Sari (2020) menemukan bahwa sebagian besar mahasiswa mengalami stres sedang $(38,57 \%)$, sebagian mengalami stress berat $(28,57 \%)$, dan stress ringan sebanyak $(32,86 \%)$. Stressor yang paling menyebabkan stress yaitu kesulitan memahami materi secara daring dan kekhawatiran tertular COVID-19.

Hasil penelitian yang lainnya menunjukkan kondisi yang berbeda seperti Suhartono (2020) pembelajaran daring mengalami perubahan yang signifikan dan model pembelajaran daring mempunyai pengaruh yang signifikan terhadap kemampuan literasi mahasiswa. Penelitian Dian, dkk (2020) menunjukkan 82\% mahasiswa mendukung dan semakin semangat dalam menyiapkan teknologi untuk modus baru pembelajaran menggunakan tuweb. Hasil ini juga sejalan dengan temuan Nariza, dkk (2020); Roida dan Yuni (2020) bahwa adanya sikap positif mahasiswa yang merasa mudah melaksanakan kuliah praktikum online. Proses belajar mengajar dapat berjalan dengan baik sebagai mana mestinya meskipun ditengah pandemi virus COVID-19.

Adanya dualisme dampak dalam pelaksanaan metode pembelajaran online/daring terhadap mahasiswa berdasarkan temuan penelitian terdahulu, beberapa penelitian selanjutnya mencoba untuk mengetahui tingkat efektivitas dan mutu model pembelajaran daring seperti Damayanthi (2020) hasil penelitiannya menunjukkan bahwa pembelajaran daring yang dilaksanakan memang cukup dapat menggantikan pembelajaran tatap muka, 
namun apabila dilihat dari efektivitas, pembelajaran daring belum mampu membuat tujuan pembelajaran tercapai. Hasil ini sejalan dengan riset sebelumnya dari Karwati (2014) bahwa pembelajaran elektronik berada dalam kategori yang tinggi, sementara kualitas pembelajaran berada dalam kategori cukup. Efektivitas pembelajaran daring di masa pandemi COVID-19 pernah dilakukan oleh Mustakim (2020); Hamdani \& Priatna (2020) pada tingkat pendidikan dasar, serta Oktavian dan Aldya (2020); Widiyono (2020) pada perguruan tinggi yang menunjukkan bahwa hasil pembelajaran yang efektif adalah apabila dilakukan secara bergantian antara daring dan luring.

Tercapainya keberhasilan metode pembelajaran daring tidak terlepas dari berbagai faktor yang menjadi penyebabnya, salah satunya adalah motivasi mahasiswa. $E$ learning dan kompetensi dosen merupakan stimulus dalam membentuk motivasi belajar mahasiswa. Menurut Sudiksa (2020) adanya e-learning akan terbentuk suatu budaya semangat belajar, dan melalui e-learning juga mendorong timbulnya ekspresi dalam diri mahasiswa untuk mau belajar menggali pengetahuan dan informasi sendiri secara aktif. Hal ini sesuai dengan pendapat Divayana (2017) yang menyebutkan bahwa kebutuhan fasilitas e-learning pada perguruan tinggi menjadi hal yang sangat penting. Selain $e$ learning, kompetensi tenaga pendidik dalam hal ini adalah dosen, merupakan faktor yang mempengaruhi motivasi dan kualitas belajar mahasiswa. Proses pembelajaran yang bermutu merupakan kemampuan dosen menggunakan seluruh komponen yang dapat mendukung terwujudnya proses pembelajaran yang bermutu (Karwati, 2014). Danim (2006) menyatakan bahwa mutu proses pembelajaran mengandung makna bahwa kemampuan sumber daya lembaga pendidikan mentransformasikan multi jenis masukan dan situasi mencapai derajat nilai tambah tertentu bagi peserta didik. Sehingga dapat dikatakan bahwa proses pembelajaran yang dilaksanakan dengan bervariasi yang lebih baik dalam meningkatkan mutu pendidikan (Karwati, 2014). Sesuai dengan rekomendasi Rakernas Kemenristekdikti 2019 bahwa SDM harus terampil dalam pemanfaatan sarana dan prasarana di era revolusi industri 4.0.

Mengacu pada Surat Keputusan Bersama 4 Menteri tentang Panduan Penyelenggaraan Pembelajaran Pada Tahun Ajaran 2020/2021 dan Tahun Akademik 2020/2021 di Masa Pandemi COVID-19 yang mengatur mengenai sistem pembelajaran yang harus dipatuhi oleh semua lembaga, STAHN Mpu uturan Singaraja mengambil langkah untuk melaksanakan sistem perkuliahan berbasis daring. Sebagai perguruan tinggi yang baru, pergeseran budaya baru yang dipicu oleh era industri 4.0 dan pandemi 
COVID-19 membawa konsekuensi bagi seluruh civitas akademika untuk mengadopsi teknologi informasi dalam implementasi pembelajaran bagi para mahasiswa. Kesiapan para dosen dan mahasiswa dituntut untuk bisa adaptif agar proses pembelajaran dapat berjalan dengan baik. Pengakajian untuk mencapai sasaran tersebut sangat penting dilakukan untuk menemukan formulasi yang tepat tentang sisitem perkuliahan online ke depan, untuk memasukkan dan membahas dalam kajian, menyertakan serta menjawab dalam kebijakan yang diambil menjadi program kerja sistem pendidikan ke depan yang komprehensip ditinjau dari berbagai sisi.

Karwati (2014) menyatakan e-learning mempermudah interaksi antara mahasiswa dengan bahan atau materi pelajaran. Demikian juga interaksi antara mahasiswa dengan dosen maupun antara sesama mahasiswa. Mahasiswa dapat saling berbagi informasi atau pendapat mengenai berbagai hal yang menyangkut pelajaran ataupun kebutuhan pengembangan diri mahasiswa. Dalam perkuliahan online dosen memiliki peran sebagai pemberi materi pembelajaran, stimulus dan arahan bagi mahasiswa (Ningsih, 2020). Stimulus yang diberikan dimaksudkan untuk membantu mahasiswa dalam memahami materi perkuliahan, sehingga memberikan hasil akhir berupa perubahan perilaku dalam belajar dan penguasaan substansi dengan baik (Yuniarti, 2010). Dampak dari perkuliahan online ini diharapkan dapat memotivasi mahasiswa dalam peningkatan kualitas pembelajaran, kemandirian belajar, selain itu dosen juga diharapkan mampu memiliki materi ajar yang lebih berkualitas dan dapat dilaksanakan kapanpun dan dimana saja (Prayudi, 2009).

Motivasi belajar tidak akan tumbuh apabila mahasiswa tersebut tidak memiliki cita-cita atau keinginan untuk belajar serta menyadari manfaat dari belajar. Oleh sebab itu seorang dosen atau tenaga pendidik perlu menggunakan cara yang tepat untuk menumbuhkan motivasi belajar mahasiswa. Pada era teknologi informasi dan komunikasi seperti sekarang ini, e-learning merupakan pilihan yang tepat dalam proses pembelajaran. Dengan desain e-learning yang menarik maka mahasiswa akan termotivasi untuk belajar. Melalui pembelajaran dengan elektronik bahan ajar bisa ditampilkan melalui media elektronik sehingga proses pembelajaran menjadi lebih menantang dan menarik bagi siswa (Wena, 2018).

Penelitian yang dilakukan Magdalena dan Napitupulu (2018), menemukan bahwa dimensi e-learning yang terdiri dari desain teknologi, pedagogik, etis dan antara muka memiliki pengaruh yang searah atau positif terhadap motivasi belajar siswa. Hasil ini 
memiliki makna bahwa meningkatnya fasilitas sarana dan prasarana e-learning akan berdampak pada meningkatknya motivasi belajar peserta didik dalam belajar (Sudiksa, dkk., 2020).

Motivasi yang tinggi akan berdampak pada minat belajar peserta didik, yang nantinya akan dapat meningkatkan hasil belajar mahasiswa (Sudiks, dkk., 2020). Kemampuan belajar peserta didik yang memiliki motivasi tinggi berbeda dengan kemampuan belajar peserta didik yang memiliki motivasi rendah. Sistem e-learning dapat menciptakan individuasi, pengayaan, akselerasi, perluasaan, produktivitas dan efektifitas dalam pembelajaran sehinggga kualitas pendidikan dapat meningkat (Yuniarti, 2010). Hal ini dikarenakan pada penyampaian data dengan media lebih menyenangkan, konten materi yang diberikan dengan jelas akan digemari sehingga mahasiswa memiliki rasa ingin tahu yang tinggi (Mustofa, dkk, 2019; Prayudi, 2009). Mahasiswa mencari sendiri pengetahuan yang dibutuhkan melalui fasilitas internet dan arahan dari dosen. Selain itu, metode ini juga membantu mahasiswa tersebut dapat belajar dimana saja dan kapan saja (Fitriasari, Tanzimah, \& Sari, 2018).

Mutu berasal dari bahasa Latin yaitu qualis, menurut Hamalik (2012) hasil belajar itu dapat terlihat dari terjadinya perubahan dari persepsi dan perilaku, termasuk juga perbaikan perilaku. Dimyati dan Mudjiono (2006) menyatakan bahwa kegiatan guru secara terprogram dan terencana dalam desain instruksional, untuk membuat peserta didik belajar secara aktif, yang menekankan pada penyediaan sumber belajar. Gage dan Berliner dalam Dimyati dan Mudjiono (2006) menyatakan bahwa belajar dapat didefinisikan sebagai suatu proses yang membuat seseorang mengalami perubahan tingkah laku sebagai hasil dari pengalaman yang diperolehnya. Oleh karena itu penggunaan istilah mutu pembelajaran secara sederhana dapat diartikan dengan kualitas ataupun keunggulan proses pembelajaran yang dilaksanakan oleh dosen, ditandai dengan kualitas lulusan atau output institusi perguruan tinggi (Karwati, 2014). Danim (2006) menyatakan bahwa mutu proses pembelajaran mengandung makna bahwa kemampuan sumber daya lembaga pendidikan menransformasikan multi jenis masukan dan situasi mencapai derajat nilai tambah tertentu bagi peserta didik.

Kesiapan lembaga pendidikan untuk melaksanakan pembelajaran daring menjadi masalah tersendiri, hal ini karena pembelajaran daring di masa pandemi dilaksanakan secara tiba-tiba, entah lembaga pendidikan itu siap atau tidak. Beberapa penelitian sebelumnya yang dilakukan oleh Sudiksa, dkk (2020); Napitupulu (2018); Karwati 
(2014) menunjukkan bahwa e-learning dan kemampuan dosen dalam mengembangkan inovasi dan kreativitas memberikan kontribusi terhadap motivasi belajar mahasiswa. Dampak dari motivasi terhadap kualitas belajar mahasiswa dengan pembelajaran daring juga dilakukan oleh Sukerti (2016). Lebih lanjut, efektivitas pembelajaran daring juga dilakukan oleh Kusnayat, dkk (2020); Damayanthi (2020). Hasil studi lain dari Aswasulasikin (2020), Suci Ferdiana (2020), Laode Anhusadar (2020), dan Zhafira et al.(2020) yang menunjukkan bahwa mahasiswa lebih menyukai media pembelajaran daring yang sudah dikenal mereka dan pembelajaran akan terasa membosankan apabila tidak ada kreativitas dari dosen dalam pembelajaran.

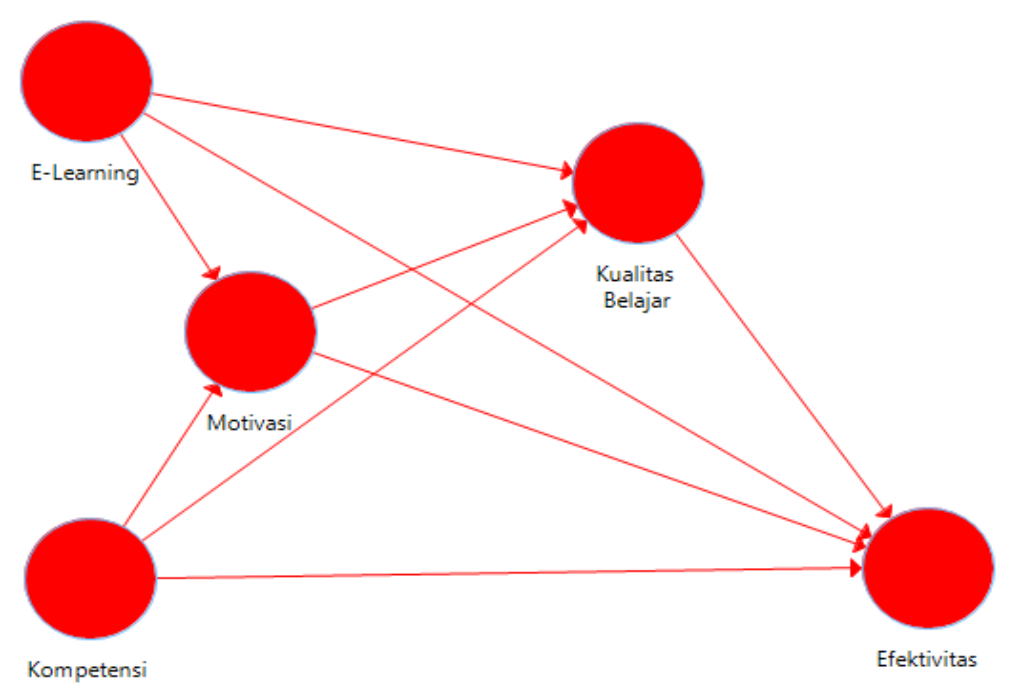

Gambar 1. Kerangka Pemikiran

\section{Metode}

Penelitian ini dilakukan di STAHN Mpu Kuturan Singaraja pada prodi ilmu komunikasi yang beralamat di Jl. Pulau Menjangan No. 27 Banyuning. Alasan pemilihan lokasi penelitian ini berkaitan dengan pengembangan program studi ilmu komunikasi dan pencapaian sasaran Renstra 2020 - 2024. Dalam penelitian ini, yang menjadi populasi penelitian adalah seluruh mahasiswa prodi ilmu komunikasi yang berjumlah sebanyak 259 orang. Untuk kebutuhan analisis dan pengujian hipotesis, seluruh populasi dijadikan sebagai sampel penelitian. Sehingga penelitian termasuk dalam penelitian populasi. Teknik analisis yang digunakan dalam penelitian ini menggunakan structural equation model (SEM) dengan program AMOS 21.0 yang terdiri dari beberapa tahapan yaitu evaluasi atas asumsi-asumsi SEM, uji reliabilitas dan validitas, analisis faktor konfirmatori, analisis full structural equation modelling (SEM), dan uji hipotesis. 


\section{Hasil Penelitian dan Pembahasan}

\section{Measurement Model (Confirmatory Factor Analysis)}

Analisis faktor konfirmatori digunakan untuk menguji unidimensionalitas dari indikator-indikator yang menjelaskan faktor laten dari konstruk eksogen dan konstruk endogen. hasil regression weights (loading factor) dari variabel laten eksogen yang disajikan dalam tabel berikut ini.

Tabel 1. Regression Weights Measurement Model Variabel Eksogen

\begin{tabular}{|lll|c|c|c|c|c|c|}
\hline & & & Estimate & S.E. & $\begin{array}{c}\text { Standardized } \\
\text { Estimate }\end{array}$ & C.R. & P & Ket \\
\hline KD8 & $<---$ & Kompetensi_Dosen & .904 & .050 & .849 & 18.163 & $* * *$ & Valid \\
\hline KD7 & $<---$ & Kompetensi_Dosen & .967 & .048 & .886 & 19.956 & $* * *$ & Valid \\
\hline KD6 & $<---$ & Kompetensi_Dosen & .941 & .047 & .889 & 20.188 & $* * *$ & Valid \\
\hline KD5 & $<---$ & Kompetensi_Dosen & .985 & .045 & .919 & 21.926 & $* * *$ & Valid \\
\hline KD4 & $<---$ & Kompetensi_Dosen & 1.009 & .047 & .911 & 21.627 & $* * *$ & Valid \\
\hline KD3 & $<---$ & Kompetensi_Dosen & 1.033 & .048 & .913 & 21.737 & $* * *$ & Valid \\
\hline KD2 & $<---$ & Kompetensi_Dosen & 1.000 & & .901 & & & Valid \\
\hline KD1 & $<---$ & Kompetensi_Dosen & 1.006 & .052 & .868 & 19.199 & $* * *$ & Valid \\
\hline EL4 & $<---$ & E_Learning & 1.000 & & .810 & & & Valid \\
\hline EL3 & $<---$ & E_Learning & 1.006 & .066 & .882 & 15.209 & $* * *$ & Valid \\
\hline EL2 & $<---$ & E_Learning & .967 & .069 & .842 & 14.027 & $* * *$ & Valid \\
\hline EL1 & $<---$ & E_Learning & .540 & .076 & .480 & 7.114 & $* * *$ & Valid \\
\hline
\end{tabular}

Sumber : Confirmatoty Factor Analysis Variabel Eksogen (data diolah)

Tabel di atas menunjukkan bahwa variabel laten E-Learning dan Kompetensi Dosen menunjukkan nilai convergent validity valid dengan nilai standardized estimate atau regression weight atau koefisien lambda ( $\lambda$ coefficient) sebesar diatas nilai 0.70 (atau rentang nilai penerimaan $0.50 \mathrm{~s} / \mathrm{d} 0.60$ masih tergolong valid). Kemudian untuk tingkat signifikansi menunjukkan bahwa semua signifikan dengan nilai CR-critical ratio diatas 1,96 dengan probabilitas atau tingkat signfikansi di bawah $0.05(\alpha=5 \%)$. Dengan demikian dapat disimpulkan bahwa semua indikator signifikan dan valid sebagai pembentuk Variabel E-Learning dan Kompetensi Dosen.

Selanjutnya hasil regression weights (loading factor) dari variabel laten eksogen yang disajikan dalam tabel berikut ini.

Tabel 2. Regression Weights Measurement Model Variabel Endogen

\begin{tabular}{|c|c|c|c|c|c|c|c|c|}
\hline & & & Estimate & S.E. & $\begin{array}{c}\text { Standardized } \\
\text { Estimate }\end{array}$ & C.R. & $\mathbf{P}$ & Label \\
\hline & $<--$ & \multirow{3}{*}{$\begin{array}{l}\text { Motivasi } \\
\text { Motivasi } \\
\text { Motivasi }\end{array}$} & 1.000 & & .871 & & & Valid \\
\hline M3 & $<--$ & & 1.100 & .057 & .923 & 19.415 & $* * *$ & Valid \\
\hline M2 & $<--$ & & 1.049 & .063 & .848 & 16.613 & $* * *$ & Valid \\
\hline
\end{tabular}




\begin{tabular}{|c|c|c|c|c|c|c|c|}
\hline & & Estimate & S.E. & $\begin{array}{c}\text { Standardized } \\
\text { Estimate }\end{array}$ & C.R. & $\mathbf{P}$ & Label \\
\hline \multirow{2}{*}{$\begin{array}{ll}\text { M1 <--- } \\
\text { KB6 <--- }\end{array}$} & \multirow{4}{*}{$\begin{array}{l}\text { Motivasi } \\
\text { Kualitas_Belajar } \\
\text { Kualitas_Belajar } \\
\text { Kualitas_Belajar }\end{array}$} & .982 & .066 & .804 & 14.819 & $* * *$ & Valid \\
\hline & & 1.000 & & .909 & & & Valid \\
\hline \multirow{2}{*}{$\begin{array}{l}\text { KB5 <--- } \\
\text { KB4 <--- }\end{array}$} & & .934 & .046 & .878 & 20.097 & $* * *$ & Valid \\
\hline & & .987 & .042 & .933 & 23.725 & $* * *$ & Valid \\
\hline \multirow{2}{*}{$\begin{array}{l}\text { KB3 <--- } \\
\text { KB2 <--- }\end{array}$} & Kualitas_Belajar & .926 & .045 & .891 & 20.670 & $* * *$ & Valid \\
\hline & Kualitas_Belajar & 1.023 & .047 & .908 & 21.810 & $* * *$ & Valid \\
\hline \multirow{2}{*}{$\begin{array}{l}\text { KB1 <--- } \\
\text { EF4 <--- }\end{array}$} & Kualitas_Belajar & .978 & .048 & .882 & 20.181 & $* * *$ & Valid \\
\hline & Efektivitas & 1.000 & & .922 & & & Valid \\
\hline \multirow{3}{*}{$\begin{array}{l}\text { EF3 <--- } \\
\text { EF2 <--- } \\
\text { EF1 <--- }\end{array}$} & Efektivitas & .995 & .044 & .912 & 22.863 & $* * *$ & Valid \\
\hline & Efektivitas & 1.071 & .046 & .917 & 23.106 & $* * *$ & Valid \\
\hline & Efektivitas & 1.072 & .050 & .896 & 21.489 & $* * *$ & Valid \\
\hline
\end{tabular}

Sumber : Confirmatoty Factor Analysis Variabel Endogen (data diolah)

Tabel di atas menunjukkan bahwa variabel laten Motivasi, Kualitas Belajar dan Efektivitas menunjukkan nilai convergent validity valid dengan nilai standardized estimate atau regression weight atau koefisien lambda ( $\lambda$ coefficient) diatas nilai 0.70 (atau rentang nilai penerimaan $0.50 \mathrm{~s} / \mathrm{d} 0.60$ masih tergolong valid). Kemudian untuk tingkat signifikansi menunjukkan bahwa semua signifikan dengan nilai CR-critical ratio diatas 1,96 dengan probabilitas atau tingkat signfikansi di bawah $0.05(\alpha=5 \%)$. Dengan demikian dapat disimpulkan bahwa semua indikator signifikan dan valid sebagai pembentuk Variabel Motivasi, Kualitas Belajar dan Efektivitas.

\section{Analisis Structural Equation Modeling (SEM)}

Setelah dilakukan analisis data menggunakan model pengukuran (analisis faktor konfirmatori) dan hasilnya mengarah kepada kesimpulan bahwa konstruk yang digunakan memiliki reliabilitas dan validitas yang baik, selanjutnya akan dilakukan analisis atas model struktural yang diajukan. 


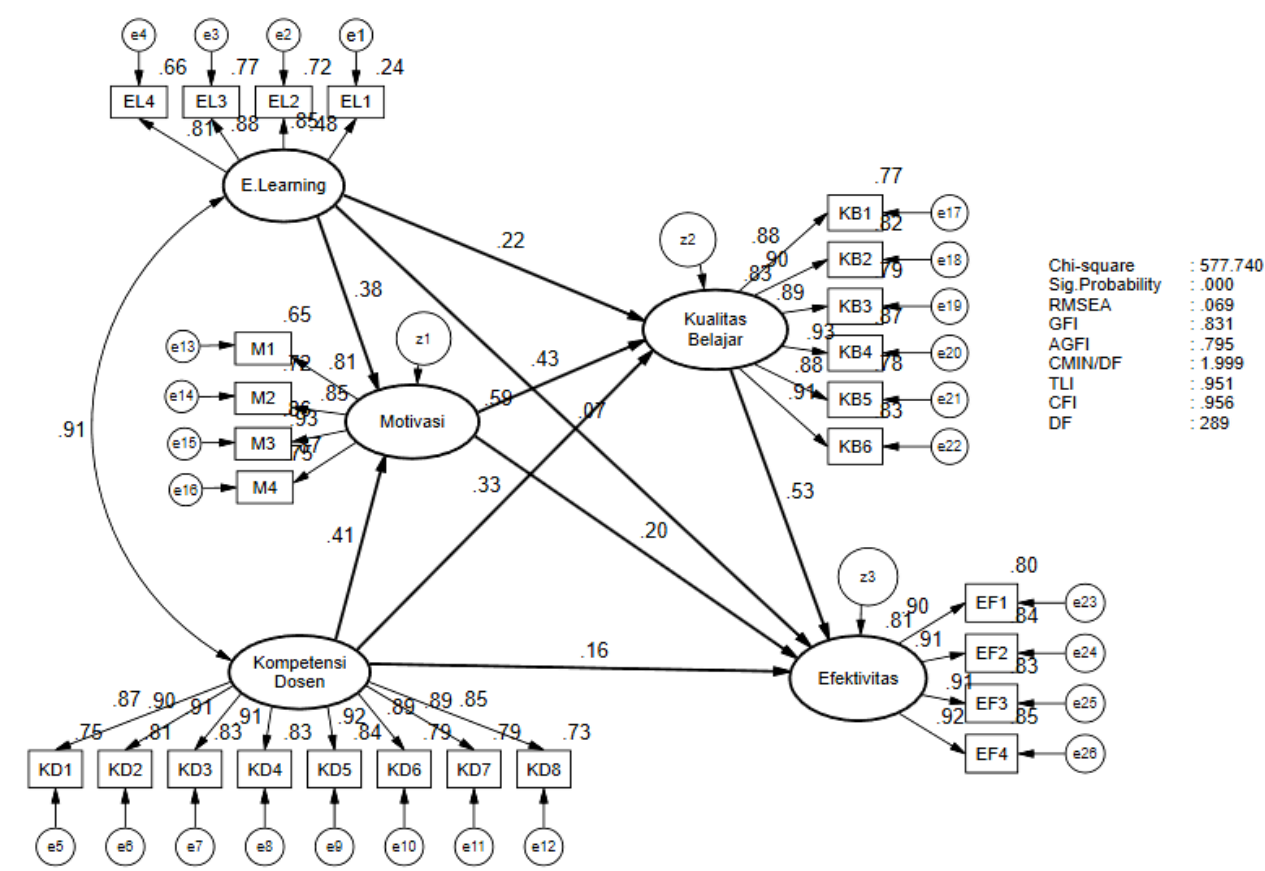

Gambar 2. Structural Equation Model (Standardized Estimates)

\section{Uji Kebermaknaan Koefisien Bobot Faktor}

Perhitungan model persamaan struktural yang merupakan hasil regression weight standardized yang menunjukkan nilai koefisien path (jalur) dari variabel-variabel yang diteliti meliputi variabel E-Learning, Kompetensi Dosen, Motivasi, Kualitas Belajar dan Efektivitas dapat dilihat yang tersaji dalam tabel berikut ini.

Tabel 3. Hasil Perhitungan Model Struktural

\begin{tabular}{|c|c|c|c|c|c|}
\hline \multicolumn{3}{|c|}{ Jalur } & C.R. & $\mathbf{P}$ & Ket. \\
\hline \multirow{9}{*}{$\begin{array}{l}\text { Motivasi } \\
\text { Motivasi } \\
\text { Kualitas_Belajar } \\
\text { Kualitas_Belajar } \\
\text { Kualitas_Belajar } \\
\text { Efektivitas } \\
\text { Efektivitas } \\
\text { Efektivitas } \\
\text { Efektivitas }\end{array}$} & $<---$ & \multirow{9}{*}{$\begin{array}{l}\text { E.Learning } \\
\text { Kompetensi_Dosen } \\
\text { E.Learning } \\
\text { Kompetensi_Dosen } \\
\text { Motivasi } \\
\text { Motivasi } \\
\text { Kualitas_Belajar } \\
\text { Kompetensi_Dosen } \\
\text { E.Learning }\end{array}$} & 2.270 & .023 & Sig. \\
\hline & $<---$ & & 2.537 & .011 & Sig. \\
\hline & $<---$ & & 1.968 & .049 & Sig. \\
\hline & $<---$ & & 3.064 & .002 & Sig. \\
\hline & $<---$ & & 6.772 & $* * *$ & Sig. \\
\hline & $<---$ & & 2.586 & .010 & Sig. \\
\hline & $<---$ & & 5.158 & $* * *$ & Sig. \\
\hline & $<---$ & & 1.375 & .169 & tdk Sig. \\
\hline & $<---$ & & .572 & .567 & tdk Sig. \\
\hline
\end{tabular}

Sumber : Analisis full structural equation model (data diolah)

Tabel di atas menunjukkan bahwa melalui pengamatan nilai CR dan $\mathrm{p}$ terlihat bahwa dari 9 (sembilan) hubungan yang dibangun, 7 (tiga) jalur menunjukkan nilai CR di atas 1,96 $(\mathrm{CR}>1,96)$ dan nilai $\mathrm{p}<0,05$ yaitu E-Learning terhadap Motivasi, Kompetensi Dosen terhadap Motivasi, E-Learning terhadap Kualitas Belajar, Motivasi 
terhadap Kualitas Belajar, Motivasi terhadap Efektivitas dam Kualitas Belajar terhadap Efektivitas. Sedangkan sisanya sebanyak 2 jalur mempunyai nilai $\mathrm{CR}<1$,96 dan nilai $\mathrm{p}$ $>0,05$ (taraf kesalahan $\alpha=5 \%$ ).

\section{Pengaruh E-Learning Terhadap Motivasi Belajar}

Berdasarkan hasil analisis yang sudah dijelaskan di depan dapat diketahui pengaruh E-Learning terhadap Motivasi adalah positif dan signifikan. Hasil ini tidak sesuai dengan Sudiksa (2020), adanya e-learning akan terbentuk suatu budaya semangat belajar, dan melalui $e$-learning juga mendorong timbulnya ekspresi dalam diri mahasiswa untuk mau belajar menggali pengetahuan dan informasi sendiri secara aktif. Hal ini sesuai dengan pendapat Divayana (2017) yang menyebutkan bahwa kebutuhan fasilitas e-learning pada perguruan tinggi menjadi hal yang sangat penting. Generasi milineal yang sudah fasih dengan perangkat teknologi informasi menjadi salah satu pemicu bahwa dengan pola pembelajaran daring (online) sesuai dengan budaya dan interkasi mahasiswa pada era sekarang. Hasil ini akan mendorong penguatan sistem dan mekanisme pembelajaran online lebih ditingkatkan melalui berbagai pendekatan sistem yang terintegrasi. Menumbuhkan semangat dan motivasi mahasiswa dalam pola pembelajaran daring merupakan salah satu tantangan dan inovasi yang terus dikelola dan dikembangkan bagi prodi dan juga tenaga pendidik.

\section{Pengaruh E-Learning Terhadap Kualitas Belajar}

Berdasarkan hasil analisis yang sudah dijelaskan di depan dapat diketahui pengaruh E-Learning terhadap Kualitas Belajar adalah positif dan signifikan. Hasil tersebut sesuai dengan hasil penelitian Karwati (2014), bahwa kontribusi e-learning sebagai variabel bebas atau variabel yang memengaruhi terhadap mutu belajar mahasiswa sebesar 0,785 atau 78,5\%. Temuan ini juga sejalan dengan Tafiardi (2005) yang menyatakan bahwa dengan perkembangan ilmu dan teknologi terutama teknologi informasi, pemanfaatan internet dalam bidang pendidikan terus berkembang. Pemanfaatan internet ini tidak hanya untuk pendidikan jarak jauh, akan tetapi juga dikembangkan dalam sistem pendidikan konvensional. E-learning adalah suatu model pembelajaran yang dibuat dalam format digital melalui perangkat elektronik. Tujuan digunakannya e-learning dalam sistem pembelajaran adalah untuk memperluas akses pendidikan kemasyarakat luas, serta dalam rangka meningkatkan mutu belajar. Temuan 
tersebut juga didukung oleh Purbo (2001) yang menyatakan bahwa paling tidak ada tiga hal dampak positif penggunaan internet dalam pendidikan yaitu: a) Peserta didik dapat dengan mudah mengambil mata kuliah di mana pun di seluruh dunia tanpa batas institusi atau batas negara; b) Peserta didik dapat dengan mudah berguru pada para ahli di bidang yang diminatinya; c) Kuliah/belajar dapat dengan mudah diambil di berbagai penjuru dunia tanpa bergantung pada universitas/sekolah tempat si mahasiswa belajar. Di samping itu kini hadir perpustakan internet yang lebih dinamis dan bisa digunakan di seluruh jagat raya.

\section{Pengaruh E-Learning Terhadap Efektivitas Belajar}

Berdasarkan hasil analisis yang sudah dijelaskan di depan dapat diketahui pengaruh E-Learning terhadap Efektivitas Belajar adalah tidak signifikan. Evaluasi ketercapaian tujuan pembelajaran juga dapat tetap diukur menggunakan aplikasi yang tersedia sehingga dosen tetap dapat mengetahui tingkat pemahaman mahasiswanya terhadap substansi perkuliahan, walaupun dengan strategi perkuliahan online. Perkuliahan online tidak luput dari beberapa masalah. Dalam perkuliahan online yang dilakukan terjadi hambatan berupa suara yang tidak terdengar dengan jelas akibat sinyal jaringan internet yang tidak kuat. Salah satu faktor yang mempengaruhi adalah terbatasnya jaringan internet terutama di daerah pedesaan Provinsi Bali. Masalah ini juga merupakan masalah nasional dan banyak dikeluhkan oleh beberapa peneliti lainnya. Disebutkan bahwa terdapat kendala yang mempengaruhi perkuliahan online, yaitu: Jaringan internet yang lemah (Mohammad Yazdi, 2012), keterbatasan dari kuota internet dalam mengakses perkuliahan (Setiawan, 2018). Lebih lanjut Wardani dkk, yang menyatakan bahwa salah satu kekurangan dari metode pembelajaran dari e-learning adalah kurangnya interaksi langsung antara mahasiswa dan dosen (Wardani, Toenlioe, \& Wedi, 2018). Kekurangan in memang akan sangat mempengaruhi keberhasilan pembelajaran, tetapi dengan bantuan aplikasi teknologi tertentu interaksi yang intensif juga dapat dilakukan, misalnya melalui penggunaan Microsoft Teams, Zoom atau aplikasi komunikasi online lainnya. Dosen masih dapat berinteraksi secara virtual dengan seluruh mahasiswa dengan menggunakan beberapa aplikasi tersebut. Sehingga, proses pembelajaran dengan metode kuliah online dapat dilakukan dengan baik. 


\section{Pengaruh Kompetensi Dosen Terhadap Motivasi Belajar}

Berdasarkan hasil analisis yang sudah dijelaskan di depan dapat diketahui pengaruh Kompetensi Dosen terhadap Motivasi Belajar adalah positif dan signifikan. Tingginya minat belajar mahasiswa disebabkan karena adanya model pembelajaran sesuai dengan selera mahasiswa. Model atau pendekatan belajar merupakan strategi atau cara yang digunakan untuk untuk menunjang efisiensi dan efektivitas proses pemberlajaran (Syah, 2010). Model pendekatan pembelajaran yang diterapkan oleh Undiknas Denpasar dengan memanfaatkan model pembelajaran elektronik (e-learning). Model e-learning menjadi lebih menyenangkan serta menarik sebab model tersebut menyedikan fasilitas interaktif seperti multimedia. Dengan adanya fasilitas multimedia ini, mahasiswa lebih cepat memahami materi-materi yang diberikan oleh dosen. Apabila materi-materi kuliah dismpaikan melalui multimedia, makan lebih mudah dimengerti oleh peserta didik. Selain itu dengan menggunakan e-learning tugas dan bahan ajar bisa dikerjakan secara interaktif dengan fleksibiltas waktu dan tempat.

\section{Pengaruh Kompetensi Dosen Terhadap Kualitas Belajar}

Berdasarkan hasil analisis yang sudah dijelaskan di depan dapat diketahui pengaruh Kompetensi Dosen terhadap Kualitas Belajar adalah positif dan signifikan. Whitaker dalam Rusman (2012) belajar adalah proses di mana tingkah laku ditimbulkan atau diubah melalui latihan dan pengalaman kegiatan belajar dan mengajar merupakan kegiatan yang paling pokok. Hal tersebut berarti berhasil tidaknya pencapaian tujuan pendidikan banyak bergantung kepada bagaimana proses belajar mengajar dirancang dan dijalankan secara profesional. Uno (2012) menyatakan bahwa belajar adalah suatu proses usaha yang dilakukan individu untuk memeroleh suatu perubahan tingkah laku secara keseluruhan sebagai hasil pengalaman individu itu sendiri dalam interaksi dengan lingkungannya. Prinsip belajar perlu sejalan dengan empat pilar pendidikan universal seperti dirumuskan oleh UNESCO, yaitu belajar untuk mengetahui (learning to know); belajar untuk melakukan (learning to do); belajar menjadi (learning to be); dan belajar untuk hidup bersama (learning to live together). Dosen harus pandai memilih materi pembelajaran yang akan disampaikan serta bagaimana proses belajar tersebut harus dikelola dan dilaksanakan di dalam kelas. Proses pembelajaran yang bermutu merupakan kemampuan dosen menggunakan seluruh komponen yang dapat mendukung terwujudnya proses pembelajaran yang bermutu. Danim (2006) menyatakan bahwamutu proses 
pembelajaran mengandung makna bahwa kemampuan sumber daya lembaga pendidikan menransformasikan multi jenis masukan dan situasi mencapai derajat nilai tambah tertentu bagi peserta didik. Sehingga dapat dikatakan bahwa proses pembelajaran yang dilaksanakan dengan bervariasi yang lebih baik dalam meningkatkan mutu pendidikan.

\section{Pengaruh Kompetensi Dosen Terhadap Efektivitas Belajar}

Berdasarkan hasil analisis yang sudah dijelaskan di depan dapat diketahui pengaruh Kompetensi Dosen terhadap Efektivitas Belajar adalah tidak signifikan. Disaat kuliah daring sekarang mahasiswa dituntut untuk tidak hanya mengandalkan penjelasan dari dosen saja namun harus menerapkan metode belajar mandiri, "Belajar mandiri diartikan sebagai kegiatan belajar aktif dengan dorongan motif untuk menguasai suatu kompetensi sehingga dapat menyelesaikan masalah serta belajar ini dibangun dari pengetahuan dan komptensi yang dimilikinya" (Mujiman, 2011). "Kemampuan untuk menyelesaikan tugas dan menentukan tujuan secara mandiri” (Trisiana, 2015). Kuliah daring memiliki berbagai dampak terhadap kemampuan mahasiswa, dampak yang terjadi pada kemampuan diri mahasiswa dapat berupa peningkatan atau bahkan penurunan, dalam dampak peningkatan dengan diterapkannya sistem perkuliahan daring membuat mahasiswa menjadi lebih mudah memahami dan mencerna dari materi yang dijelaskan dan bagi mahasiswa yang tidak menyukai proses pembelajaran secara bersamamaan dengan orang banyak menjadi lebih nyaman dan lebih mudah dalam memahami materi yang diberikan, dan juga membuat kemampuan mahasiswa lebih meningkat dalam memahami bagaimana penggunaan dan pemanfaatan media yang digunakan sebagai sarana pelaksanaan proses pembelajaran.

\section{Pengaruh Motivasi Belajar Terhadap Kualitas Belajar}

Berdasarkan hasil analisis yang sudah dijelaskan di depan dapat diketahui pengaruh Motivasi terhadap Kualitas Belajar adalah positif dan signifikan. Penyelenggaraan kegiatan pembelajaran elektronik, dosen merupakan faktor yang sangat menentukan dan keterampilannya memotivasi mahasiswa menjadi hal yang krusial. Karena itu, dosen haruslah bersikap transparan menyampaikan informasi tentang semua aspek kegiatan pembelajaran sehingga mahasiswa dapat belajar secara baik untuk mencapai hasil belajar yang baik. Informasi yang dimaksudkan di sini menyakup hal-hal di bawah ini: 1. Alokasi waktu untuk mempelajari materi pembelajaran dan penyelesaian 
tugas-tugas. 2. Keterampilan teknologis yang perlu dimiliki mahasiswa untuk memperlancar kegiatan pembelajarannya, dan 3. Fasilitas dan peralatan yang dibutuhkan dalam kegiatan pembelajaran. Mutu pembelajaran pada hakikatnya adalah target yang harus dicapai dosen dalam melaksanakan proses pembelajaran. Mutu belajar hanya akan dicapai dosen dengan memberikan pelayanan yang baik dan memuaskan terhadap mahasiswa, karena dengan pelayanan yang baik dan dapat memuaskan mahasiswa, maka proses pembelajaran dapat mencapai tujuan yang telah ditetapkan. Surya dalam Rusman (2012) menyatakan bahwa belajar dapat diartikan sebagai suatu proses dilakukan oleh individu untuk memeroleh perubahan perilaku baru secara keseluruhan, sebagai hasil dari pengalaman itu sendiri dalam berinteraksi dengan lingkungannya. Peningkatan etos kerja akan merupakan palengkap dari usaha untuk meningkatkan mutu produk kerja dan semangat profesionalisme. Keberhasilan atau kegagalan dosen dalam meningkatkan mutu hasil pendidikan, profesionalisme, dan etos kerja akan dapat dirasakan oleh masyarakat melalui profil para lulusannya.

\section{Pengaruh Motivasi Belajar Terhadap Efektivitas Belajar}

Berdasarkan hasil analisis yang sudah dijelaskan di depan dapat diketahui pengaruh Motivasi terhadap Efektivitas Belajar adalah positif dan signifikan. Motivasi dan belajar memiliki hubungan yang erat dan saling mempengaruhi. Motivasi belajar dapat tumbuh karena adanya dua faktor, yaitu faktor dari dalam dirinya sendiri (intrinsik) dan faktor dari luar dirinya sendiri (ekstrinsik). Kedua faktor ini dapat tumbuh karena adanya rangsangan tertentu sehingga mahasiswa berkeinginan untuk belajar. Dengan adanya rangsangan belajar melalaui $e$-learning maka akan dapat menumbuhkan semangat dan gairah belajar. Motivasi belajar masing-masing mahasiswa sangat berbeda, tergantung dari sosial budaya mahasiswa. Mahasiswa asing akan memiliki motivasi belajar yang berbeda dengan mahasiswa lokal (Kazakova dan Shastina, 2019). Motivasi belajar tidak akan tumbuh apabila mahasiswa tersebut tidak memiliki cita-cita atau keinginan untuk belajar serta menyadari manfaat dari belajar. Oleh sebab itu seorang dosen atau tenaga pendidik perlu menggunakan cara yang tepat untuk menumbuhkan motivasi belajar mahasiswa. Pada era teknologi informasi dan komunikasi seperti sekarang ini, e-learning merupakan pilihan yang tepat dalam proses pembelajaran. Dengan desain e-learning yang menarik maka mahasiswa akan termotivasi untuk belajar. Melalu pembelajaran dengan elektronik bahan ajar bisa ditampilkan melalui media 
elektronik sehingga proses pembelajaran menjadi lebih menantang dan menarik bagi siswa (Wena, 2018). Penelitian yang dilakukan Magdalena dan Napitupulu (2018), menemukan bahwa dimensi e-learning yang terdiri dari desain teknologi, pedagogik, etis dan antara muka memiliki pengaruh yang searah atau positif terhadap motivasi belajar siswa. Hasil ini memiliki makna bahwa meningkatnya fasilitas sarana dan prasarana elearing akan berdampak pada meningkatnya motivasi belajar peserta didik dalam belajar. Begitu pula pengaruh e-learning terhadap kolaborasi siswa, e-learning memiliki pengaruh yang positif terhadap kolaborasi belajar siswa. Ini memiliki makna bahwa semakin baik sarana prasarana e-learning maka semakin tinggi minat siswa untuk melakukan kerja bersama dalam memecahkan suatu masalah.

\section{Pengaruh Kualitas Belajar Terhadap Efektivitas Belajar}

Berdasarkan hasil analisis yang sudah dijelaskan di depan dapat diketahui pengaruh Kualitas Belajar terhadap Efektivitas Belajar adalah positif dan signifikan. Sejauh ini telah ada beberapa penelitian yang dilakukan untuk melihat bagaimana pembelajaran daring dilakukan di masa pandemi COVID-19 ini seperti yang dilakukan oleh Luh Devy Herliandry et al (2020), Sulata \& Hakim (2020), Wahyu Aji Fatma Dewi (2020), Ali Sadikin dan Afreni Hamidah (2020). Penelitian yang dilakukan oleh Firman \& Sari Rahayu (2020) menunjukkan hasil bahwa mahasiswa perlu memiliki perangkat pembelajaran yang mendukung dan mampu melihat bahwa sistem pembelajaran daring yang fleksibel mampu membentuk kemandirian belajar dan motivasi belajar mahasiswa. Penelitian yang membahas tentang persepsi mahasiswa terhadap kuliah daring di masa pandemi COVID-19 seperti yang dilakukan oleh Aswasulasikin (2020), Suci Ferdiana (2020), Laode Anhusadar (2020), dan Nabila Hilmy Zhafira et al.(2020) yang menunjukkan bahwa mahasiswa lebih menyukai media pembelajaran daring yang sudah dikenal mereka dan pembelajaran akan terasa membosankan apabila tidak ada kreativitas dari dosen dalam pembelajaran.

Sementara penelitian yang dilakukan untuk melihat bagaimana efektivitas pembelajaran daring di masa pandemi covid-19 pernah dilakukan oleh Mustakim (2020), Acep Roni Hamdani dan Asep Priatna (2020) pada tingkat pendidikan dasar, serta Riskey Oktavian dan Riantina Fitra Aldya (2020), Aan Widiyono (2020) pada perguruan tinggi yang menunjukkan bahwa hasil pembelajaran yang efektif adalah apabila dilakukan secara bergantian antara daring dan luring. Kemampuan dosen dan mahasiswa dalam 
menggunakan teknologi informasi dan komunikasi dalam pembelajaran daring berpengaruh terhadap capaian tujuan pembelajaran. Ketidaksiapan dosen maupun mahasiswa dalam menggunakan platform pembelajaran daring menjadi salah satu masalah yang dapat menghambat efektivitas pembelajaran daring. Dosen dan mahasiswa harus beradaptasi dengan kebiasaan baru berinteraksi belajar menggunakan media daring. Dosen diharapkan mampu menggunakan teknologi sebagai sarana untuk menyampaikan pembelajaran kepada mahasiswa. Penyiapan materi pembelajaran berbasis teknologi yang menarik minat mahasiswa untuk belajar, kemampuan menggunakan media pembelajaran daring, serta kemampuan menggantikan suasana kelas tatap muka yang selama ini dilakukan secara langsung ke dalam suasana kelas daring sehingga mahasiswa tetap merasa nyaman mengikuti pembelajaran menjadi faktor penting bagi mahasiswa dapat menerima pembelajaran daring. Sementara mahasiswa diharapkan mampu menggunakan media pembelajaran daring baik untuk pertemuan maupun untuk menyampaikan hasil tugas. Tidak semua mahasiswa mampu memahami materi yang diberikan selama pembelajaran daring (Wijaya et al., 2020).

\section{Kesimpulan}

Berdasarkan hasil penelitian yang telah dilakukan dapat disimpulkan beberapa hal penting. Variabel E-Learning berpengauh positif dan signifikan terhadap Motivasi Belajar, hasil ini memberikan arti bahwa adopsi teknologi informasi sebagai komponen penunjang dalam penerapan pembelajaran e-learning di masa pandemi covid-19 memiliki sumbangan positif dan nyata terhadap mahasiswa dalam hal motivasi belajar. Variabel $E$ Learning berpengauh positif dan signifikan terhadap Kualitas Belajar, hal ini memberikan arti bahwa semakin intensif pembelajaran e-learning di masa pandemi covid-19 dilakukan dengan berbagai kreatifitas dosen maka kualitas belajar mahasiswa akan tercapai dengan maksimal. Variabel E-Learning berpengauh tidak signifikan terhadap Efektifitas Belajar, temuan ini memberikan arti bahwa pada beberapa kasus, metode penerapan e-learning belum maksimal tercapai. Variabel Kompetensi Dosen berpengauh positif dan signifikan terhadap Motivasi Belajar, hasil ini memberikan arti bahwa peran dosen dalam melakukan berbagai inovasi pembelajaran online mampu menumbuhkan semangat dan motivasi belajar mahasiswa. Variabel Kompetensi Dosen berpengauh positif dan signifikan terhadap Kualitas Belajar, artinya bahwa peran dosen dalam menyiapkan dan memanfaatkan berbagai sarana dan prasarana pembelajaran online 
secara nyata dapat meningkatkan kualitas belajar mahasiswa. Variabel Kompetensi Dosen berpengauh tidak signifikan terhadap Efektivitas Belajar, hal ini memberikan arti bahwa harus ada perubahan pola dan pendekatan yang dilakukan dalam interaksi dengan mahasiswa dalam kegiatan pembelajaran online. Variabel Motivasi Belajar berpengauh positif dan signifikan terhadap Kualitas Belajar, temuan ini memberikan arti bahwa kemampuan dosen dalam memotivasi mahasiswa akan meningkatkan kualitas belajar secara online. Variabel Motivasi Belajar berpengauh positif dan signifikan terhadap Kualitas Belajar, hasil ini memberikan arti bahwa kemampuan dosen dalam memotivasi mahasiswa akan meningkatkan kualitas belajar secara online. Variabel Motivasi Belajar berpengauh positif dan signifikan terhadap Efektivitas Belajar, artinya terbentuknya semangat dan minat yang tinggi dalam proses pembelajaran online akan meningkatkan efektivitas belajar mahasiswa. Terakhir, Variabel Motivasi Belajar berpengauh positif dan signifikan terhadap Efektivitas Belajar, artinya bahwa terbentuknya semangat dan minat yang tinggi dalam proses pembelajaran online akan meningkatkan efektivitas belajar mahasiswa.

\section{Daftar Pustaka}

Arizona, K., Abidin, Z., \& Rumansyah, R. (2020). Pembelajaran Online Berbasis Proyek Salah Satu Solusi Kegiatan Belajar Mengajar Di Tengah Pandemi COVID-19. Jurnal Ilmiah Profesi Pendidikan, 5(1), 64-70. https:// doi.org/10.29303/jipp.v5i1.111

Damayanthi, Adriana (2020). Efektivitas Pembelajaran Daring di Masa Pandemi Covid19 Pada Perguruan Tinggi Keagamaan Katolik. Edutech 19(3), 2020.

Divayana, D. G. H. (2017). Evaluasi pemanfaat e-learning menggunakan model CSEUCLA. Cakrawala Pendidikan. Th. XXXVI(2), 280-289.

Ferdinand, Augusty (2006). Structural equation modeling dalam penelitian manajemen. Badan Penerbit Universitas Diponegoro, Semarang

Ferdinand, Augusty (2006). Metode penelitian manajemen : pedoman penelitian untuk penulisan skripsi, tesis dan disertasi ilmu manajemen. Badan Penerbit Universitas Diponegoro, Semarang

Fitriasari, P., Tanzimah, T., \& Sari, N. (2018). Kemandirian belajar mahasiswa melalui blended learning pada mata kuliah metode numerik. Jurnal Elemen, Vol. 4(1), 1. https://doi.org/10.29408/jel.v4i1.439. 
Ghozali, Imam (2008). Model Persamaan Struktural : Konsep \& aplikasi dengan program AMOS 16.0. Badan Penerbit Universitas Diponegoro, Semarang

Ghozali, Imam (2009). Aplikasi analisis multivariate dengan program SPSS. Badan penerbit universitas Diponegoro, Semarang

Hair, Joseph F., Jr., et.al. (1998). Multivariate data analysis. fifth edition. USA : prenticeHall International, Inc.

Hair, Joseph F., Jr., et.al (2006). Multivariate data analysis. sixth edition. New Jersey : Pearson educational, Inc.

Herliandry, L. D., Nurhasanah, N., Suban, M. E., \& Kuswanto, H. (2020).Pembelajaran Pada Masa Pandemi COVID-19. JTP - Jurnal Teknologi Pendidikan, 22(1), 6570. https://doi.org/10.21009/ jtp.v22i1.15286

Irhandayaningsih, A. (2020). Pengukuran Literasi Digital Pada Peserta Pembelajaran Daring di Masa Pandemi COVID-19. Anuva, 4(2), 231-240.

Jusmawati, Satriawati, Bellona Mardhatillah Sabillah (2020). Pengaruh pembelajaran berbasis daring terhadap minat belajar mahasiswa pgsd unimerz pada mata kuliah pendidikan matematika.

Karim, Bisyri Abdul (2020). Pendidikan Perguruan Tinggi Era 4.0 Dalam Pandemi Covid-19 (Refleksi Sosiologis). Education and Learning Journal Vol. 1, No. 2, Juli 2020, pp. 102-112

Karwati, Euis (2014). Pengaruh pembelajaran elektronik (e-learning) terhadap mutu belajar mahasiswa.

Kusnayat, Agus; Moh. Hifzul Muiz; Nani Sumarni; Agus Salim Mansyur; Qiqi Yuliati Zaqiah (2020). Pengaruh Teknologi Pembelajaran Kuliah Online di Era Covid-19 dan Dampaknya Terhadap Mental Mahasiswa. Jurnal Edukasi dan Teknologi Pembelajaran Volume 1, No. 2 Edisi Juni 2020

Kusnendi, (2008). Model-model persamaan struktural : satu dan multigroup sampel dengan Lisrel. Penerbit Alfabeta, Bandung

Mustakim. (2020). Efektivitas Pembelajaran Daring Menggunakan Media Online Selama Pandemi COVID-19 Pada Mata Pelajaran Matematika the Effectiveness of ELearning Using Online Media During the COVID19 Pandemic in Mathematics. Al Asma: Journal of Islamic Education, 2(1), 1-12. 
Mustofa, M. I., Chodzirin, M., Sayekti, L., \& Fauzan, R. (2019). Formulasi model perkuliahan daring sebagai upaya menekan disparitas kualitas perguruan tinggi. Walisongo Journal of Information Technology, Vol. 1(2), 151. https://doi.org/10.21580/wjit.2019.1.2.4067.

Ningsih, Desak Made Rai (2020). Pengaruh Metode Kuliah Online Terhadap Tingkat Pemahaman Materi Kuliah Hukum Investasi Pada Mahasiswa Universitas Teknologi Indonesia. Jurnal Pendidikan, Volume 21, Nomor 2, September 2020, 104-110

Oktavian, R., \& Aldya, R. F. (2020). Efektivitas Pembelajaran Daring Terintegrasi di Era Pendidikan 4.0. Didaktis: Jurnal Pendidikan Dan Ilmu Pengetahuan, 20(2), 129135. https://doi.org/10.30651/ didaktis.v20i2.4763

Prayudi, Y. (2009). Prosiding seminar nasional aplikasi teknologi informasi (SNATI). Kajian Awal: E-Learning REadiness Index (ELRI) sebagai model bagi evaluasi e-learning pada sebuah institusi, 2009 (Snati). Retrieved from http://journal.uii.ac.id/index.php/Snati/article/view/953/909.

Sudiksa IM , DGH Divayana, IWS Warpala (2020). Pengaruh e-learning dan lingkungan kampus terhadap minat belajar mahasiswa dengan motivasi belajar sebagai variabel mediasi. Jurnal Teknologi Pembelajaran Indonesia

Sukerti, N. M. B. (2016). Pengaruh model pembelajaran inkuiri terbimbing dan motivasi belajar terhadap hasil belajar IPA. Tesis (Tidak diterbitkan). Program Magister Teknologi Pembelajaran Program Pascasarjana Universitas Pendidikan Ganesha. Widiyono, A. (2020). Efektifitas Perkuliahan Daring (Online) pada Mahasiswa PGSD di Saat Pandemi Covid 19. Jurnal Pendidikan, 8(2), 169-177. https://doi.org/10.36232/ pendidikan.v8i2.458

Yuniarti, R. D. (2010). Meningkatkan kualitas pembelajaran di Prodi Tata Niaga Jurusan pendidikan ekonomi FPEB-UPI. 8(16), 66-77. 